\title{
Government Communication Strategy of Bandung City in Socialization of Regulation Concerning Administrative Sanctions of Littering
}

\author{
Tatik Fidowaty \\ Lecturer of Government Science \\ Universitas Komputer Indonesia \\ Bandung, Indonesia \\ tatik.fidowaty@email.unikom.ac.id
}

\author{
Olih Solihin \\ Lecturer of Communication Science \\ Universitas Komputer Indonesia \\ Bandung Indonesia \\ olihmail@gmail.com
}

\author{
Poni Sukaesih Kurniati \\ Lecturer of Government Science \\ Universitas Komputer Indonesia \\ Bandung, Indonesia \\ poni.sukaesih@email.unikom.ac.id
}

\begin{abstract}
The purpose of this study was to determine the communication strategy of the Bandung City government in the dissemination of regulations on administrative sanctions to litter. This study uses a descriptive research method with a qualitative approach. Data collection techniques that are used are literature studies, observation, interviews and documentation studies. The technique of determining the informant uses a purposive for the government apparatus and accidental for Bandung City community. The results showed that the socialization carried out by the government on administrative sanctions for disposing of arbitrary waste has not been effective because of the unsustainability of socialization carried out by the government and the imposition of administrative sanctions that are not strict so that the community becomes indifferent to the regulation. The conclusion is that cleanliness is a shared responsibility so that the community, and the government must work together in protecting the environment by not littering because it will result in floods and other disasters. The strategy carried out by the Bandung city government in the socialization of administrative sanctions to create littering has not been carried out effectively because of constraints on the amount of budget and human resources that are still lacking both in quantity and quality.
\end{abstract}

Keyword: Communication strategy, socialization littering

\section{INTRODUCTION}

In essence, strategy is a way or management planning to achieve a goal. The strategy is used not only to achieve the goal, but serves as a road map that shows the direction, besides that the strategy must show how the operational tactics [1]. The success or failure of a communication strategy is determined by the systematic ability between the various components involved. This component is the answer to the question in Lasswell's statement that the best way to explain communication activities is to answer the question "who, says what, in which channel, to whom, with what effect". Who asks who is the communicator ?, says what asks what message to say ?, in which channel asks what media is used, to whom to ask who is the communicator? and with what effect ask what effect is expected? [2].

This kind of research has been investigated by several researchers namely Brown, Terry J., Sam H. Ham, and Michael Hughes with the title taking garbage: a theory-based communication application to influence tourist behavior in protected areas [3]. Then research from Cho, Seong Eun,
Myunggoon Choi, and Han Woo Park with the title of civilgovernment conflict and communication strategy: text analysis from the tv debate about the import of beef from Korea [4]. Furthermore, research by Steyn, Benita entitled from the strategy of communication strategies to the company: a conceptualization [5]. In addition, research conducted by OSullivan, G. A., et al. With the title Field Guide to designing health communication strategies. resources for health professional communication [6]. The latest research references examined by May, Yeo Ming, Seow Ting Lee, and Suliman Al-Hawamdeh with the title formulating a communication strategy for sharing effective knowledge [7]. The research equation conducted by the researchers with the five studies above is equally researching about communication strategies but different in terms of research focus and research locus.

This study aims to find out the communication strategy of the Bandung City government in the socialization of regulations regarding administrative sanctions to litter. The regional government of the city of Bandung tried to socialize regional regulations No. 11 of 2005 concerning the implementation of order, cleanliness and beauty (K3) [8], by using effective communication strategies but have not succeeded because there are problems in the enforcement of $\mathrm{K} 3$ regional regulations in particular the prohibition of littering, namely the lack of synchronization between the government and the community as objects in the application of the regional regulation. The community considers the government to be less serious in implementing regulations regarding the prohibition of littering. In addition, not all people know and understand the contents of the regional regulations compiled by the government because many people have not received socialization, so the government is deemed to have failed in disseminating regulations about the prohibition of littering.

In general, regional regulations No. 11 of 2005 concerning the implementation of orderliness, cleanliness and beauty (K3), regulates 68 actions that are prohibited or will be subject to fines if violated. While the regulations relating to the act of disposing of garbage or cleanliness there are 18 verses. The sanctions ranging from the lightest are a fine of Rp. 250,000.00 to the highest fine of $\mathrm{Rp}$. $50,000,000.00$ or a three-month confinement. Regarding the enforcement of the regulation, the Mayor of Bandung then issued Mayor Regulation No. 522 of 2007 concerning the 
procedure for implementing administrative sanctions against violations of the Bandung City Regulation No. 03 of 2005 concerning the implementation of order, cleanliness and beauty as amended by the Bandung City Regulation No. 11 of 2005 [9].

In Regional Regulation No. 11 of 2005 concerning the organization of order, cleanliness and beauty, Article 49 paragraph 1 letter f reads:

"Do not provide a trash can in the front yard, subject to the imposition of a law enforcement cost of $\mathrm{Rp}$. $250,000.00$ (two hundred fifty thousand rupiahs), and / or administrative sanctions in the form of temporary detention of Resident's Identity Card, or other Population Identity Card, Disturbance Permit, SIUP, SIUK, or other permits, as well as installation / attachment of stickers / boards announcement of statements as violators, and / or announcements in the mass media ".

In the article above each house is required to have a trash bin but there are still many houses that do not have a trash can so that the residents of the house throw litter, often they throw garbage into drains or sewers. Even though throwing trash into a water channel or ditch in Article 49 paragraph 1 letter ggg will be imposed a fine of Rp. 5,000,000.00 and / or administrative sanctions in the form of temporary detention of Identity Card, or other Population Identity Cards, and / or announcements in the media time. Enforcement K3 regional regulations that are currently being discussed at this time are Article 49 paragraph 1 letter $n$ which reads:

"Do not equip the trash can on vehicles transporting passengers and / or goods, littering, throwing garbage out of the vehicle, is subject to imposition of law enforcement costs of Rp. 250,000.00 (two hundred fifty thousand rupiahs), and / or administrative sanctions in the form of temporary detention of a Citizen Identity Card, or other Population Identity Card, Route Permit, and the attachment of a statement sticker as a violator, and / or an announcement in the mass media ".

After the raid on the trash bin began to take place on December 1, 2014, many vehicles were netted and did not have a garbage box. However, vehicle owners who do not have a garbage box have not been fined, they are still given a reprimand. The granting of fines will take effect on Monday, December 8, 2014. Owners of the netted vehicles argue that they have not received socialization from the government so they are not aware of any regulations that each vehicle must have a garbage box.

\section{METHOD}

This study uses a descriptive research method with a qualitative approach. Data collection techniques used are literature studies, non-participant observations, interviews conducted in August 2016 and documentation studies. The technique of determining the informant uses a purposive for the Hygiene Service apparatus and accidental for the K3 regional regulation object, namely the people of Bandung City.

\section{RESULTS AND DISCUSSION}

The results of the research on the socialization of the regulations on administrative sanctions littering carried out by the Bandung City government are seen from the AIDDA approach (Attention, Interest, Desire, Decision, Action) [10], are as follows: First, seen from Attention, the results of the research show that the Bandung city government as a communicator has tried to arouse the attention of communicants (the community) so as not to litter by socializing local regulations on administrative sanctions littering through socialization and guidance in sub-districts, mass media and electronics and other cleaning activities.

The neighborhood association (RT) and the Community Unit (RW) as the smallest government structure play an important role in socializing the regional regulation prohibiting the disposal of garbage to the community, because RT and RW can directly touch the community. Household waste is usually managed by RT and RW, but not all RT and RW have a good performance in the socialization of the prohibition of littering, so there are still many people who throw garbage litter especially if the position of their house is times or land is not used. The reason is that people throw garbage carelessly because in their RT or RW the waste management has not run well, not all houses have a trash bin and do not want to pay a garbage fee even though the waste rate is relatively cheap. Another cause of people still littering is because of the indecisiveness of sanctions in littering and entrenched bad habits that have been embedded in our society that littering is not wrong. Many people have not yet realized the impact of littering, even though the city of Bandung is often flooded because of culverts or waterways or not being able to function properly because they are filled with garbage.

So far the sanctions are still not implemented, when there are people who are caught hand-throwing littering they are only given a warning, in photos and photos uploaded on social media (social media) then just released is not directly fined. According to researchers uploading photos to social media did not give a deterrent effect, the people who uploaded their photos when littering were not famous, respected or influential people so they would not get public attention. People will only see then forget about the incident. Administrative sanctions should be immediately carried out to attract public interest.

Interest is the second approach, after the community gives attention it will continue with interest. People are still indifferent. Communication carried out by the government to the community is still not able to attract the interest of the community, it happened because the socialization carried out by the government did not run continuously. For example, just about socialization that every four-wheeled vehicle such as a private car or public vehicle (bus, public transportation, etc.) must have a garbage box, so they don't throw garbage on the road from the car while driving. But this only lasts a little. Socialization is not carried out continuously because of lack of costs.

Third, in view of Desire, there is only desire in the communicant, the communicator does not mean anything. Desire does encourage people to take action. For this desire must be directed to positive things. The government as a communicator should be able to provide a desire for the community not to throw garbage randomly through effective 
communication. That desire will arise if the community's interest has grown first. For this reason socialization should be made as attractive as possible to arouse the desire of the community.

Campaigns carried out using social media have also been carried out such as using Facebook, Twitter, Instagram and Youtube. This media does not require expensive fees and is not limited by time space. Technological sophistication is utilized by the government to help complete its tasks. If we look at the social media owned by PD this kebershan is not much seen / followed by the community. For example, Instagram is only followed by 453 folowing or twiter which is only folow by 804 people. Whereas the population of Bandung City in 2014 was recorded based on the Population Service 2,748,732 people, with the presence of commuter / urban $+3,000,000$ people. This shows that the community's desire to care about waste and its environment is very small. This is a very unfortunate thing that means socialization using Medsospun has not been effective. Seeing the number of people who use this PD cleanliness social media.

Fourth, seen from the Decision, the results of the study show that the city government of Bandung has not been able to make a good communication strategy that is able to arouse the public to make decisions not to litter. The socialization of administrative sanctions littering has not gone well. People are still indifferent to the regulation. To be able to influence the community's decision to dispose of garbage in its place, a good strategy is needed. If it is not persuasively treated then it must be with strict sanctions.

The government has to apply the sanctions not just socialization. If we look at other countries such as Singapore that are clean, one of the causes is the existence of strict sanctions against the public in violation of the rules. When Indonesians are in Singapore they are able to obey the rules and throw trash in their place but why when in their own country do they throw garbage litter? According to the researchers this happened because the application of regulations that were less assertive in our homeland, the rule breakers often accepted the acceptance of law enforcement officials so that people did not respect the existing regulations, let alone there is the term "law can be bought".

Fifth, in view of the Action, action is a continuation of the decision, namely the decision to take what further action must be taken by the community after getting socialization. A good communicator (government) must have the ability to change attitudes, behavior and actions of the community, if after socialization of administrative sanctions littering but the community keeps littering, it is necessary to review the content of administrative sanctions to throw garbage, it could be the community considered that the regulation could not be implemented, so the people were indifferent. Minimal supervision is one of the causes, even though there are already garbage patrol supervisors but the number of personnel is still very small, if the community remains unaware of the dangers of littering then the socialization that has been done will be in vain.

The tendency of our society to obey the rules when there is someone watching but if no one is watching, then they will do whatever they want by littering. Awareness must be planted as early as possible for our society. The city government of Bandung tries to instill awareness to the young generation by creating a program for the Garbage
Collection and GPS "(Heroes of Bandung Urang) as volunteers who play a direct role to uphold the law on cleanliness in the city of Bandung. Prabu consists of elementary, junior high, high school students in Badung City as well as mothers and fathers from several RT / RW and their village to read Prabu's pledge as a commitment to help maintain and uphold cleanliness. The Prabu will be marked with pins and each RT will have 2 Prabu for regional, and one class 2 for school children. In addition, the city government of Bandung made the Kang Pisman program.

All forms of socialization that have been carried out by the government show a desire to make Bandung a city that is free from waste. But as a Communicator, the city government of Bandung has not been able to change the behavior of communicants (community). The government should be smarter in conveying the contents of the message and what media are most effective to use.

\section{CONCLUSION}

Cleanliness is a shared responsibility so that the community and the government must work together in protecting the environment by not littering because it will result in floods and other disasters. The strategy carried out by the Bandung city government in the socialization of administrative sanctions to create littering has not been carried out effectively because of constraints on the amount of budget and human resources that are still lacking both in quantity and quality. In addition, the lack of awareness of the people of the city of Bandung itself for cleanliness is one of the obstacles in implementing the regional regulations.

\section{ACKNOWLEDGMENT}

Thank to the Unikom Rector, Dr. Ir. Eddy Soeryanto Soegoto who has provided support both morally and materially in this research. And than the Ministry of Research, Technology and Higher Education of the Republic of Indonesia has provided educational support of materially.

\section{REFERENCES}

[1] Effendy, Onong Uchjana. "Ilmu Komunikasi Teori dan Praktek. Bandung: PT Remaja Rosdakarya. (2005): 32

[2] Lasswell, Harold (1948). Bryson, L., Ed. The Structure and Function of Communication in Society. The Communication of Ideas. New York: Institute for Religious and Social Studies, 117.

[3] Brown, Terry J., Sam H. Ham, and Michael Hughes. "Picking up litter: An application of theory-based communication to influence tourist behaviour in protected areas." Journal of Sustainable Tourism 18.7 (2010): 879-900.

[4] Cho, Seong Eun, Myunggoon Choi, and Han Woo Park. "Government-Civic Group Conflicts And Communication Strategy: A Text Analysis Of Tv Debates On Koreas Import Of Us Beef." Journal of Contemporary Eastern Asia 11.1 (2012): 1-20.

[5] Steyn, Benita. "From strategy to corporate communication strategy: A conceptualisation." Journal of Communication Management 8.2 (2004): 168-183.

[6] OSullivan, G. A., et al. "A field guide to designing a health communication strategy. a resource for health communication professionals." (2003)

[7] Mei, Yeo Ming, Seow Ting Lee, and Suliman Al-Hawamdeh. "Formulating a communication strategy for effective knowledge sharing." Journal of Information Science 30.1 (2004): 12-22. 
[8] Peraturan daerah No. 03 Tahun 2005 tentang penyelenggaraan ketertiban, kebersihan dan keindahan (K3) sebagaimana telah diubah dengan Peraturan daerah No. 11 Tahun 2005.

[9] Peraturan Walikota No. 522 Tahun 2007 tentang tata cara pelaksanaan penegakan sanksi administrasi terhadap pelanggaran Peraturan daerah K3

[10] Yukl, Gary. 2009. Kepemimpinan Dalam Organisasi. Terjemahan oleh Budi Supriyanto. Jakarta: P.T. Indeks 